\title{
Häufig verwendete Abkürzungen (nach Liddell/Scott/Jones)
}

\section{Platons Schriften}

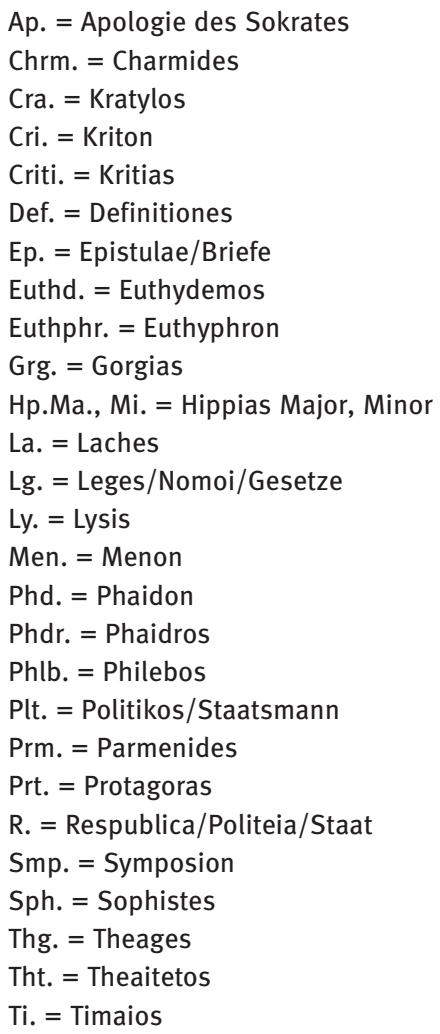

\section{Aristoteles' Schriften}

\author{
APo. = Analytica Posteriora \\ APr. = Analytica Priora \\ Cat. = Categoriae/Kategorienschrift \\ de An. = de Anima \\ $\mathrm{EE}=$ Ethica Eudemia/Eudemische Ethik \\ $\mathrm{EN}=$ Ethica Nicomachea/Nikomachische Ethik \\ $\mathrm{GA}=$ de Generatione Animalium
}


X — Häufig verwendete Abkürzungen (nach Liddell/Scott/Jones)

$\mathrm{GC}=$ de Generatione et Corruptione

Metaph. = Metaphysica

$\mathrm{PA}=$ de Partibus Animalium

Ph. = Physica

Pol. = Politica

Rh. = Rhetorica

$\mathrm{SE}=$ Sophistici Elenchi

Top. $=$ Topica

Das ausführliche Abkürzungsverzeichnis nach LS) ist im Internet verfügbar unter http://stephanus.tlg.uci.edu/lsj/01-authors_and_works.html 